\title{
中山間地域における沿道の茶園景観の特徵に関する研究
}

\section{Research for Features of Tea Plantation Landscape on the Roadside of Mountainous Region}

\author{
木村 真也* 村上 修一** \\ Shinya KIMURA Shuichi MURAKAMI
}

\begin{abstract}
The objectives of this study are figure out, a) the visibility of tea plantation in Oku-eigenji district, Higashioumi city, Shiga prefecture, b) the features of landscape in this region from relationship tea plantation with other elements, c) and the factor associated with the visibility of tea plantation or the features of landscape by fieldwork, analyzing topographical map, analyzing VTR from the passenger seat of the vehicle, and analyzing still image extracted from VTR. Visibility of tea plantation is not high. We could not see majority. All visible tea plantations are located the place where form of tea plant and management state is seen well. The glimpse of tea plantation that is alternated visibility interval and invisibility interval is repeated. The feature of this region is tea plantations in short-distance view, houses or trees in middle-distance view, and mountain in far-distance view. But house or mountain is not included in screen because of view point. Tea plantation is distributed within village or forest margin. Therefore it is screened by houses, trees, and microtopography. On the other hand these factors of invisible characterize the landscape of this region as glimpse of tea plantation on sequential landscape.
\end{abstract}

Keywords: tea plantation landscape, visibility, mountainous region, roadside landscape, landscape agriculture, cultural landscape

キーワード: 茶園景観, 可視性, 中山間地域, 沿道景観, 景観農業, 文化的景観

\section{1. 研究の背景 ·目的}

国内の中山間地域では古くから茶園が営まれてきた。その理由 として, 斜面地は塩基類の流出が多く畑作に適さないが好酸性の 茶樹は栽培可能なこと, 山間部の気象条件が高級茶の生産に適し ていることが挙げられる 1)。また，現在では国内の茶園の 8 割が ヤブキタをはじめとする優良品種で占められ大規模な展開も可能 となっているが，かつては在来種のヤマチャが用いられていた。 谷口 (1936 年) 2 )鳥屋尾(1996 年) 3 の調査報告は全国各地の中山 間地域でヤマチャによる茶園が営まれていたことを示す。しかし 過疎高齢化により，中山間地域では集落の維持が難しい状況とな っている。そのため人々の営為によって支えられてきた中山間地 域の景観は存続の危機に瀕し, 茶園も例外ではないと考えられる。

一方，人々の営為によって支えられてきた景観の文化的な価值 の高まりから，その保全継承に向けた取り組みが国内各地で進ん でいる 4)。景観の保全継承が観光をはじめ地域の振興にも寄与し 得る可能性に鑑みると, 対象となる景観の特徵をいかに把握し地 域の景観計画に反映させるかが課題の 1 つとして浮上する。茶園 景観については, 荒井ら (2010 年) 5)により, 近代以前の茶産地 25 地域の発祥要因，形成過程，地形構造が明らかにされている。し かし，実際に茶園の成寸景観の特徵にまで踏み込んでいない。一 方，大井川中流域の茶園景観を対象として，鈴木ら (2009年) 6)に より静止画像を使用した, 車空景観の分析と評価が行われ, 奥ら (2009 年)7)により日中の来訪者評価の比較が行われており, 前述 の課題に対する知見が得られている。しかし，比較的大規模な茶 園が広がる中流域の景観が対象であり，冒頭で述べたような山間 部で営まれてきたヤマチャの茶園を対象とした景観研究は既往例 がない。

中山間地域の茶園景観の特徵を景観計画一反映すること想定し， 茶園景観を来訪者の観賞行為の対象として位置づけるには, 以下 のような問題が想定される。国内の旅行では, 利用交通機関の 3 割が自家用車で最多である ${ }^{8)}$ 。特に公共交通網の脆弱な中山間地
域では，ほとんどの来訪者が車利用となり，移動する車両の内部 から景観を観賞する割合が高いと考えられ，山間部の地形や密集 した集落により, 沿道からの茶園の可視性が低いことが予想され る。つまり, 沿道からは茶園が見えづらく, そもそも観賞の対象 となりえないのではないかといら問題が考えられる。

そこで, 後述する中山間地域の茶園景観を対象に車両移動中の 来訪者による景観体験を想定した方法で, 調査分析を行い，a）沿 道からどの程度見えるのかという茶園の可視性を明らかにし，b） 諸要素との関係から当該景観の特徴を明らかにし，c）茶園の可視 性や景観の特徴の要因を明らかにすることを, 本研究の目的とす る。本研究の成果は，来訪者の景観体験を想定した上で，茶園景 観の特徴を明らかにすることから，茶園を景観資源として位置づ け，観光を視野に入れた中山間地域の振興に向けて，茶園景観の 特徴を踏まえた景観計画を策定するための知見として有用である。

一方, 本研究はシークエンス景観の研究としても位置づけられ る。雨宮ら (2001 年) 9)は街路景観を車両から撮影したVTR の抽 出画像を用いて街路樹景観を類型化し, 街路樹の修景効果を明ら かにした。加藤ら (2004 年) 10)は近世城郭跡で撮影された画像を用 いて，景観構成要素，注視形態，SD 法による評価から，シーク エンス景観の判定要因を明らかにした。また柳田ら (1989 年) ${ }^{11)}$ は鉄道の車空景観について, 車空景観のタイプ分類, SD 法によ る印象評価を行い, 車空景観の特徽を明らかにした。本研究は, これらシークエンス景観の研究による蓄積を, 中山間地域の茶園 景観に活用する初例として独自性を有する。

\section{2. 研究の方法}

\section{（1）対象地域·対象路線の概要}

滋賀県東近江市の奥永源寺地域（図 - 1) は, 三重県との県境に 位置し，鈴鹿山脈の山麓から山裾にかけて広がる農山村地域であ る。森林が地域全体の面積の $90 \%$ を占め, 琵琶湖に注ぐ愛知川の 源流域が成すV字谷にあたり, 衤畑(たではた), 黄和田(きわだ),

滋賀県立大学環境科学研究科

炏滋賀県立大学環境科学部 


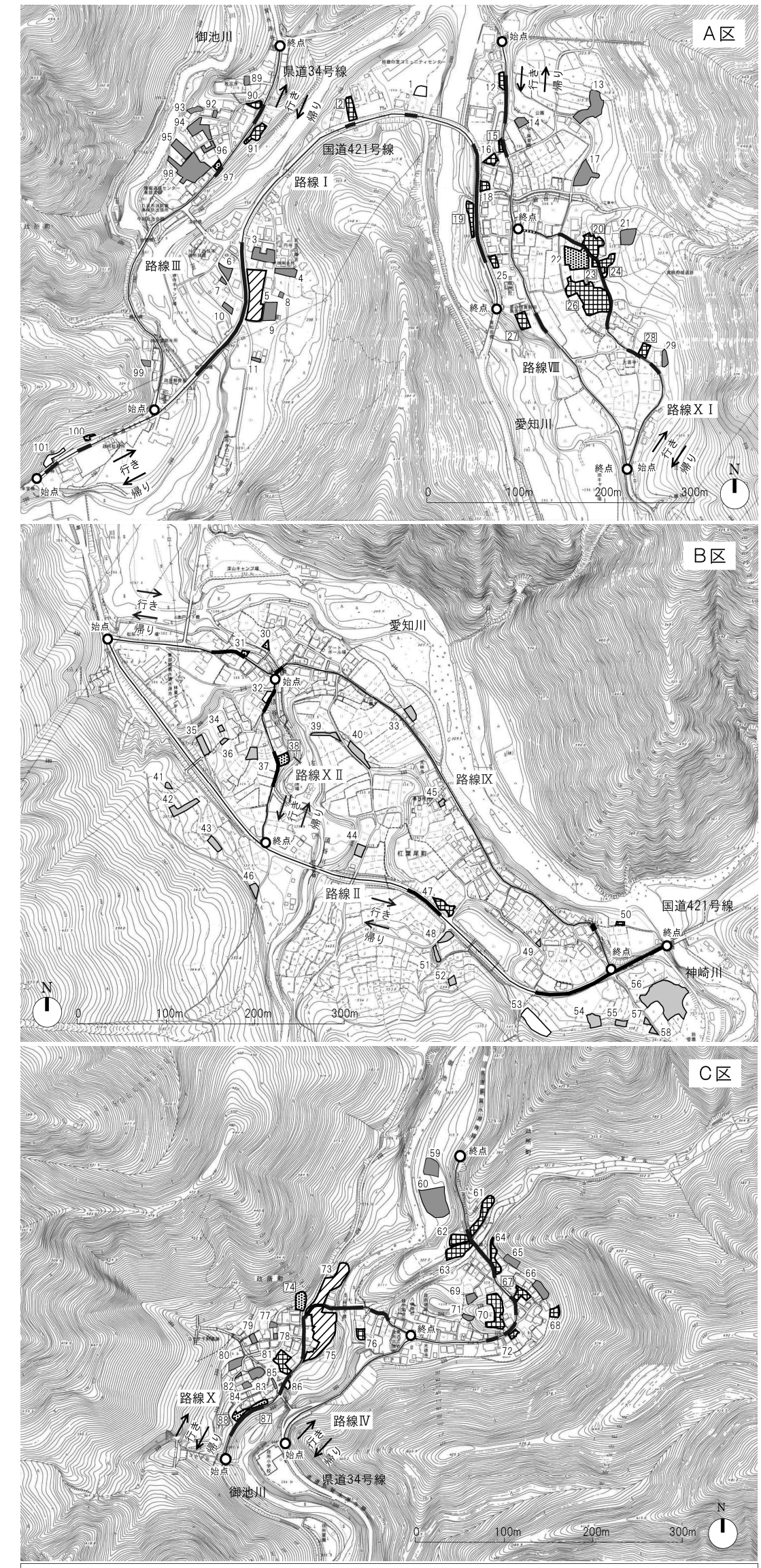

凡例

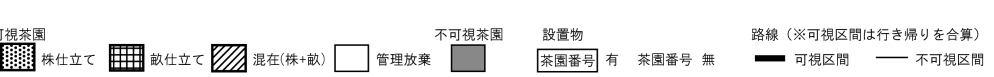

左 : 図 - 2 可視不可視茶園分布状況亡調査対象路線一覧図 右 : 図 - 3 路線毎の可視区間

(図 - 2, 図 - 3 は次頁に続く)

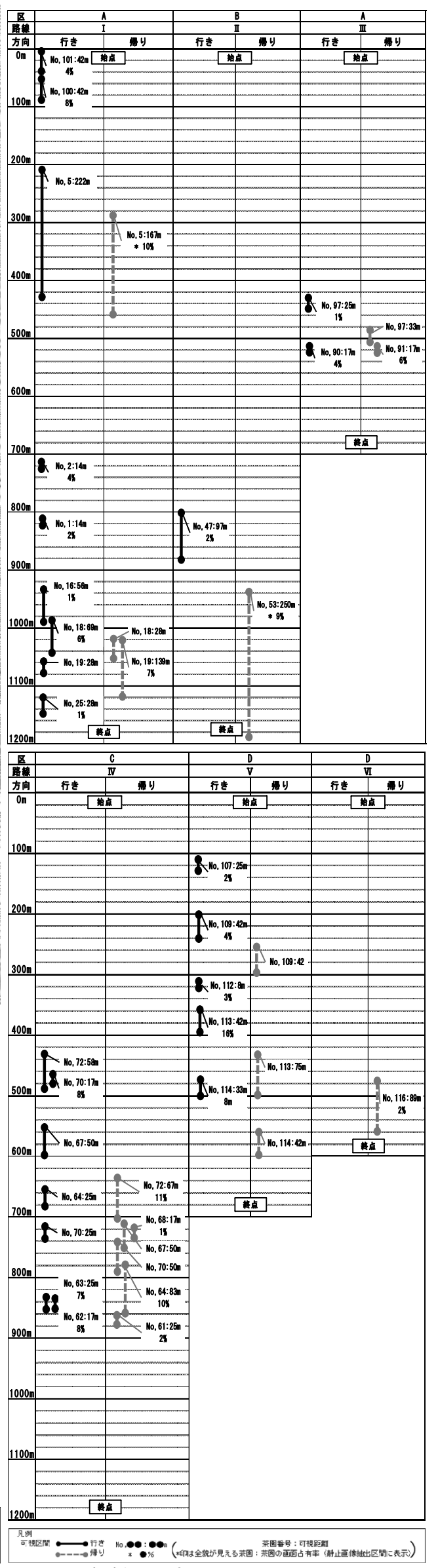



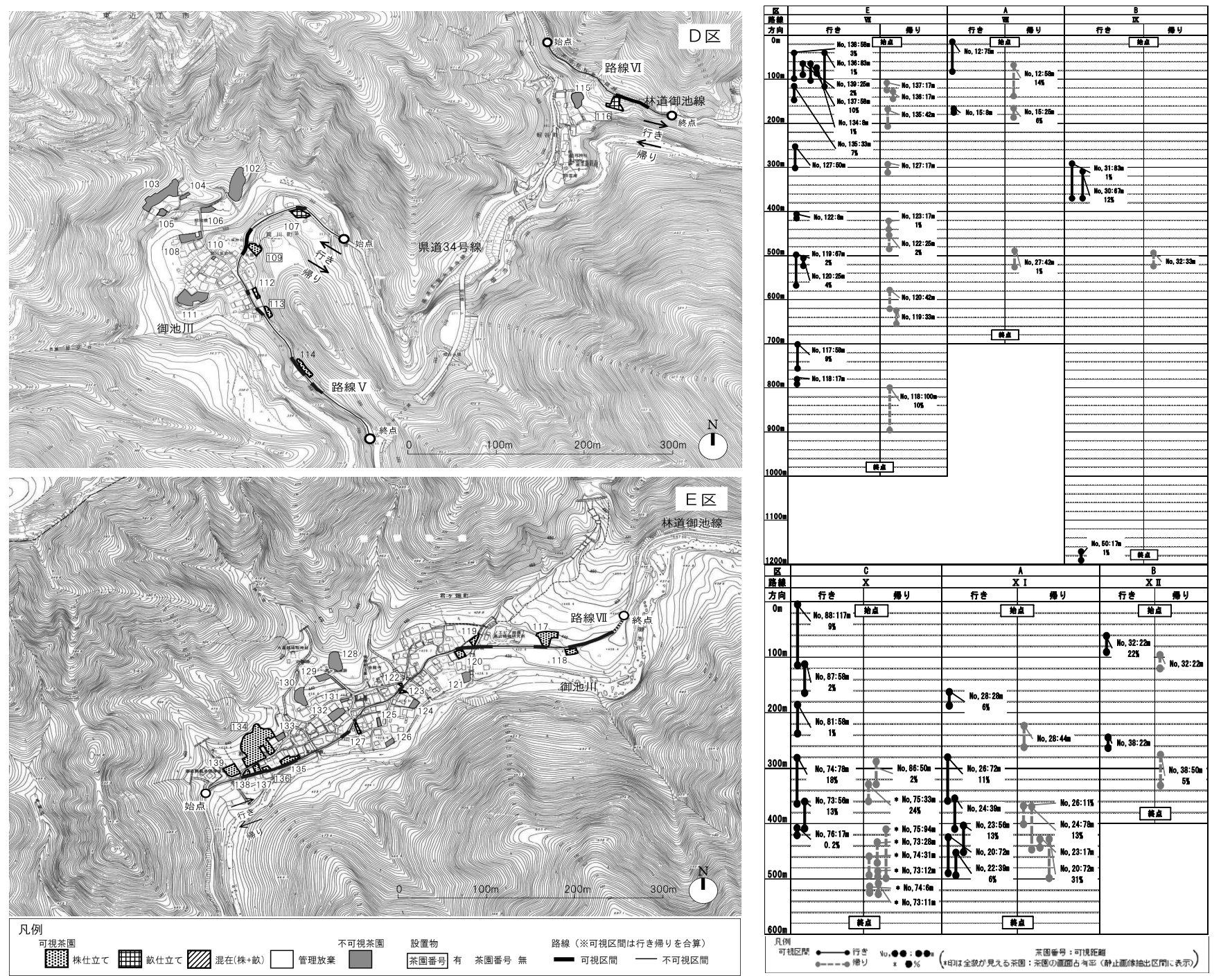

左 : 図 - 2 可視不可視茶園分布状況之調査対象路線一覧図 右 : 図 - 3 路線毎の可視区間

(図 - 2, 図 - 3 は前頁の続き)

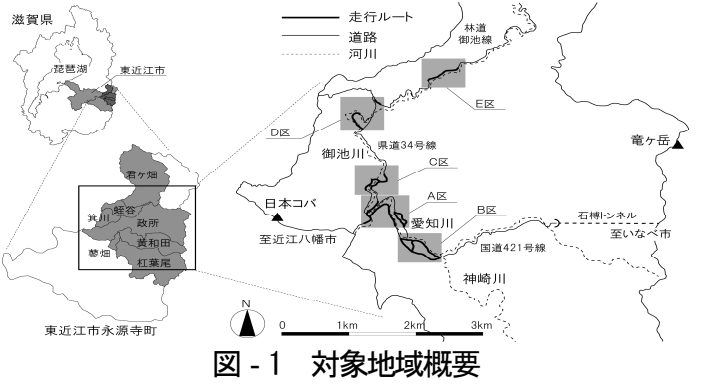

杜葉尾(ゆずりお)の 3 町が点在する本流に, 政所(まんどころ), 箕川(みのかわ), 蛭谷(ひるたに)，君ヶ畑(きみがはた)の 4 町が 点在する御池川が，蓼畑で合流する。古くから茶園を生業として 営み,「政所茶」の名で全国に知られてきた。公共交通機関は定期 バスのみであることから，主な移動手段は自家用車となり，他地 域からの来訪も自家用車が主である。2011年 3 月に開通したバイ パストンネルによる利便性向上の影響により，沿道開発が行われ 茶園が消滅する危険性と, 急勾配の山間部内の, 狭小な平坦部に 小規模な集落と耕地が点在し，移動手段が車両移動に限定されて いるといった，国内の中山間地域における典型的な地理状況を有 することから，本地域を対象とした。

また，対象路線は，本地域内の幹線道路(国道 421 号線，県道
34 号線, 林道御池線) から 7 路線(路線 I 〜路線VII), 車両が通行 できる車道, 軽車道を含む生活道路から 5 路線(路線VIII 路線 X II) である。選定理由としては，茶園を望むことができること， また，来訪者を想定し， 2 方向から進入退出できる道路であるこ ととした。各路線の位置については, 図-1, 図-2 に示す。

\section{(2) 方法}

本研究では，来訪者の車空からの景観体験を想定する。まず景 観対象となる茶園の状況について把握するために，地形図分析と 現地調查により, 茶園の分布状況, 属性を把握し, その上で, 車 両助手席からのVTR 分析を行うことで, 沿道のシークエンス景 観の特徴を明らかにした。具体的には，茶園分布状況について， 地形図 (1/2500, 2009 年東近江市作成) と, 地形図には表れない 詳細な状況を補完するために, 2009 年 8 月〜2010 年 8 月にかけ て現地調査を行い，地図上に茶園位置をプロットするとともに， 茶樹の形状，茶園の管理状況，茶園周囲の設置物の有無について 把握した。茶園の単位は，田畑の数え方と同様に「枚」とした。 景観要素として茶園を捉える本研究の趣旨から, 所有者による区 分ではなく, 切れ目無く 1 つにまとまっている茶園を 1 枚として 数えた。そのようにして地形図上にプロットした茶園について, $\mathrm{CAD}$ でトレースして水平投影面積を算出し, 茶園の面積とした。 また, 地形図の等高線から茶園の立地する斜面の傾斜度を求めた。 茶園 - 路線間の距離については, 路線と茶園を最短で結ぶ法線の 
茶園と路線を最短で結ぶ法線の両端の高低差を地形図の等高線に もとづいて読み取った。

次に，車空からのシークエンス景観の特徴を明らかにした。具 体的に，対象地域の主な移動手段が自家用車であること，景観体 験の再現性が高い9)ことから, 本研究では, 車両の助手席から見 える連続した景観を想定し, 景観を記録するメディアとして,

VTR を使用した。撮影は近景から遠景まで見渡せる晴天日 (2011 年 7 月 3 日， 4 日: 13 時〜 16 時)に行った。選定した路線を含む 道路を普通自動車(車種 : スズキエスクード, 車高 : $1.7 \mathrm{~m}$ )で走行 し, 速度は路線の状況(道路幅, 道路傾斜, 交差点の有無)に合わ せ，時速 $5 \mathrm{~km} \sim 50 \mathrm{~km}$ の範囲内の速度で走行した。茶園は走行路 線の両側に分布寸るため，行き帰りの 2 方向走行し，両脇の沿道 景観を記録した。ビデオカメラは助手席の位置に，搭乗者の視線 の高さ(視点高 : $1.6 \mathrm{~m}$ ) で，進行方向より沿道方向に約 15 度振つ た状態で，固定し，画角は50 度となるように設定した9)。調査に 使用した車両は, SUV 型であるため, カメラの取付け位置は, 歩 行者の視線の高さと同等である。VTRにおいて, 視認できる茶園 を可視茶園とし, 視認できない茶園を不可視茶園とした。そして, 可視茶園については, 茶園を確認し, 見えなくなるまでの距離を, VTR と地形図を照合して，路線上にプロットし，距離を CAD で トレースすることで，算出した。次に, VTR における各茶園の画 面占有率が，最も大きい静止画像を抽出し，走行中継続して見ら れる, 空, 道路以外の構成要素について, $\mathrm{CAD}$ によて各要素 をトレースすることで, 各要素の画面占有率を求め, 景観構成を 把握した。また, VTRで視認できない不可視の茶園については, 不可視の茶園を望むことができる箇所を地形図で確認し, VTR と 照合することで，全画像において，茶園を遮蔽している要素を把 握した。

\section{3. 結果}

\section{（1）現地調査および地形図分析の結果}

\section{1) 対象地の概況}

本地域の標高は 270 $1240 \mathrm{~m}$ と広範囲にわたるが, 集落は標高 290～450m に集中し，谷底に沿って立地している。集落の外縁 部にはスギ林やヒノキ林がある。それより上部は山林が占め，下 部の谷底には川が流れている。集落間には幹線道路が通り，集落 内部に生活道路が通っている。

2) 茶園の分布

現地調查より，本地域には 139 枚の茶園が分布していることが わかった（図－2）。標高 290４50m に分布しており，集落の立地 寸る標高と一致している。全ての茶園は谷底に位置し，集落内部 の家屋と近接した場所, または集落背後の林縁部に分布している。 3 ) 茶園の属性

茶園の面積については最小 $8 \mathrm{~m}^{2}$, 最大 $1322 \mathrm{~m}^{2}$, 平均 $188 \mathrm{~m}^{2} て ゙$, 50〜100 m゙が最も多く, $200 \mathrm{~m}^{2}$ 未満のものが 7 割を超え，ほとん どの茶園は小規模である(図 - 4)。茶園が立地する斜面の傾斜度 については，55 枚の茶園が 3 度未満の傾斜に立地し，30 度未満 の斜面には全体の 9 割を超え，樹園地等の耕作に適した傾斜の土 地 12 ) への立地が認められた(図 - 5)。また，茶樹の形状について は，一株ごとに半球状に整枝されている株仕立ては 74 枚, 複数 の茶樹を列状に整枝した畧仕立ては 37 枚，株仕立てと畧仕立て が混在する茶園は 8 枚であり, 在来茶園とされる株仕立てが多く 残存していることが確認された。茶園の管理状況については，整 枝されておらず，地表面に雑草が繁殖し，管理放棄されている茶 園が 20 枚確認され，9割弱の茶園が維持管理されている。

4) 茶園と路線の位置関係

茶園 - 路線間の距離は最小 $3 \mathrm{~m}$, 最大 $117 \mathrm{~m}$ で, $5 \mathrm{~m}$ 以上 $10 \mathrm{~m}$ 未 満の茶園が 26 枚と最も多く, 路線から $50 \mathrm{~m}$ 以内に位置する茶園
表 - 1 路線詳細
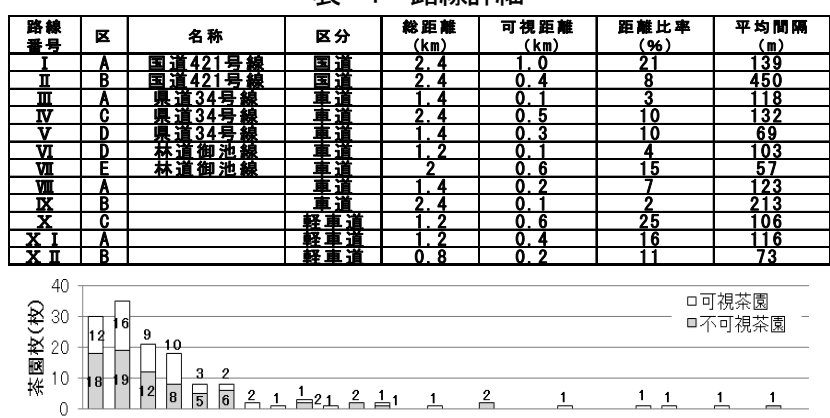

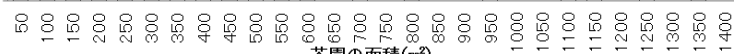

図 - 4 茶園の面積

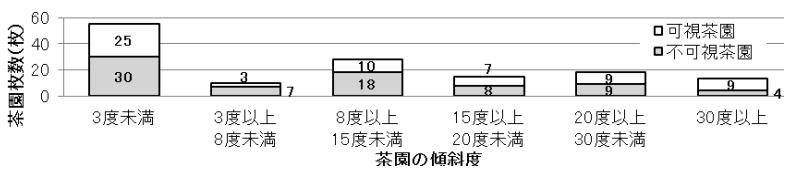

図 - 5 茶園の傾斜度

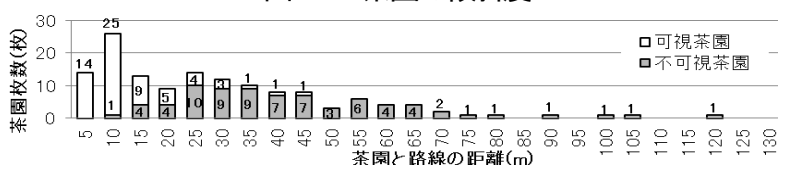

図 - 6 茶園一路線間の距離

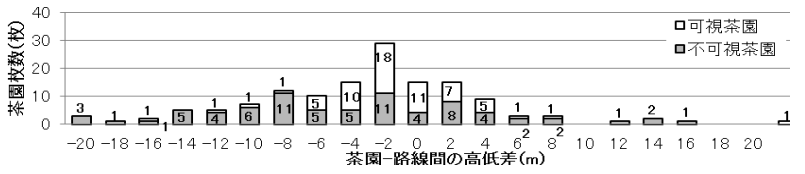

図 - 7 茶園 - 路線間の高低差

が 8 割である(図 - 6)。また, 茶園 - 路線間の高低差については, $-20 \mathrm{~m} \sim+20 \mathrm{~m}$ に分布し, $-2 \mathrm{~m}$ 以上, $0 \mathrm{~m}$ 未満が 29 枚と最も多く, 高低差 $\pm 10 \mathrm{~m}$ 末満の茶園が全体の 8 割を占める(図 - 7)。

(2) VTR による分析の結果

1 ) 可視茶園の特徵

VTRの分析結果より，車両助手席から視認できる可視茶園は 63 枚で全体の 4 割であった(図 - 2 に可視茶園の分布を示す)。全 貌を視認できる茶園は 5 枚のみであり，可視茶園の 1 割にも満た ない。茶園 - 路線間の距離を示寸図 - 6 では可視不可視の区別を しているが, このグラフで示されるように可視茶園は路線から $45 \mathrm{~m}$ 以内に立地している。

また, 茶園の可視区間について, 各路線の地形図上の始点から 出発し, 終点で折り返し，始点に至るまでの区間にプロットした 結果を図 - 3 に示す。各茶園における，可視区間の合計值は No. 5 (図 - 2 の茶園番号以下同じ) が最長で $389 \mathrm{~m}$, No. $112 ， 134$ が 最短 $8 \mathrm{~m}$, 平均して $78 \mathrm{~m}$ であり, $120 \mathrm{~m}$ 以下に 9 割の茶園が含ま れる(図 - 3)。路線の端部を除いた, 可視区間の間隔については, 最長 $533 \mathrm{~m}$, 最短 $8 \mathrm{~m}$, 平均 $114 \mathrm{~m}$ である。路線の総距離に占め る, 可視区間の割合について, 最大は路線Xの $25 \%$, 最小は路線 IXの $2 \%$ であり，平均で $11 \%$ ある(表 - 1)。図 - 3 は可視区間と 不可視区間が交互に現れる様子を示している。そこで各区間の総 和を区間数で除し，区間が交互に現れる平均距離を算出したとこ ろ表 - 1 のようになった。最小は路線 V, VII，VIIIの $8 \mathrm{~m}$ から最大 は路線 II $861 \mathrm{~m}$ までの值を示し, 全体の平均は $117 \mathrm{~m}$ となった。

2 ) 茶園の遮蔽要素

全体 139 枚から可視茶園 63 枚を引いた, 76 枚は不可視茶園で ある(図 - 2 に不可視茶園の分布を示寸)。茶園景観を遮蔽してい る要素は, (1)家屋, (2)樹林, (3)茶園と路線の高低差が確認された(図

-10)。家屋と樹林については, 茶園を視認できる方向に要素が 


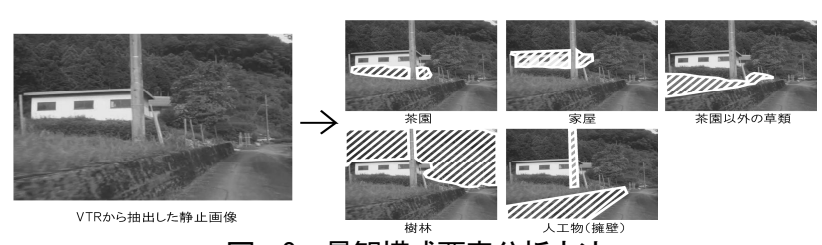

図 - 8 景観構成要素分析方法

(斜線部力対象とした景観要素)

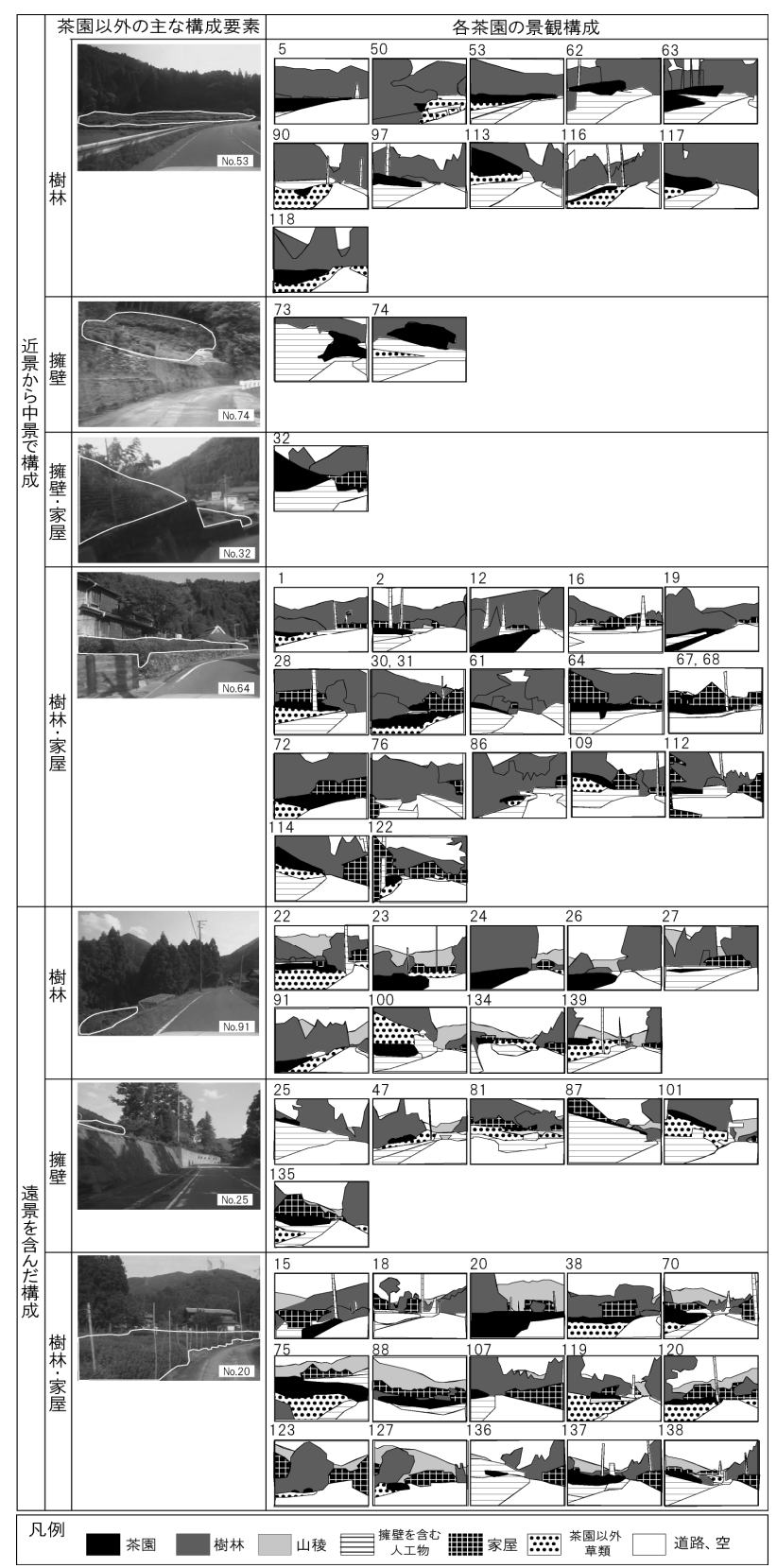

図 - 9 茶園景観の構成

(画像白線内部力茶園)

建ち上がることで，背後の茶園を遮蔽している場合を要素として 判定した。高低差については, 茶園の方が路線より高く法面に隠 れて視認できない場合，茶園の方が低く手前の地面に隠れて視認 できない場合，平坦な立地において，地形の高低差ではなく，手 前の茶園の茶樹に隠れて奥の茶園が視認できない場合を遮蔽要素 と判定した(模式図を図 - 10 に示寸)。家屋の場合が 31 例，樹林 の場合が 22 例, 高低差については, 法面に隠れる場合が 23 例, 手前の地形に隠れる場合が 3 例, 手前の茶園に隠れる場合が 1 例 であった。

\section{（3）静止画像による分析の結果}

各茶園の画面占有率が最も高い静止画像 63 枚をVTR より抽出 した。画像の分析例を図-8 8 亿示寸。画像中の要素を識別し, 要 素別に輪郭をトレースした。また，樹林の樹冠や茶園の株など要 素のディテールをとらえることができる場合を近景, 山肌を構成 する樹木の輪郭をとらえられないなど均質に見える場合を遠景, その中間を中景として区別し 13)，その妥当性については地形図で 当該要素と視点との距離を求めることて確認した。

分析の結果，茶園の画面占有率はNo.20 が最大 $31 \% ， N o .76$ で最小 $0.2 \%$, 平均 $19 \%$ であり, $15 \%$ 未満に可視茶園の 9 割が含 まれる(図 - 3 に茶園ごとの画面占有率を示した)。全ての茶園は 近景であるが，これは画面占有率が最も高い静止画像を抽出して いるためであり，シークエンス景観においては，中景に確認され た茶園が近景に移動する例も確認された。また現地調查による目 視では進行方向右側にも茶園は確認されたが，遠方の茶園は山林 や家屋により遮蔽され確認できなかった。茶園以外の構成要素に ついては, 樹林と擁壁の画面占有率の大きさが顕著である。特に, No. 90 において樹林が 50\%を占め，No. 73 において擁壁が 50\% を占めた。

画面を構成する主な要素の種別と, 近景, 中景, 遠景の区別に 着目し，63枚の分析図を分類したところ，図-9 のように整理す ることができた(No.30, 31 と No.67, 68 は同一画像であるため, まとめて図示)。画面を構成する要素の組み合わせでは, 樹林と茶 園, 擁壁と茶園, 擁壁・家屋と茶園, 樹林・家屋と茶園の 4 通り が認められた。また，各組み合わせの中で，近景から中景までに 限られる場合と，近景から遠景にまでわたる場合とが認められた が，擁壁・家屋と茶園の組み合わせは近景から中景までに限られ る場合のみである。それぞれの該当数は図 - 9 のとおりである。 樹林・家屋との組み合わせが最多であり, 次が樹林との組み合わ せである。遠景を含む場合と含まない場合はほぼ同数である。

\section{4. 考察}

\section{（1）茶園の可視性}

不可視茶園が 76 枚と過半数を占めること，全貌を視認できる 茶園は可視茶園の1割に満たないことから，本地域の沿道におけ る茶園の可視性は高くないと言える。各路線に占める可視区間の 割合が平均すると 1 割にすぎないこと，ほとんどの茶園の画面占 有率が $15 \%$ 未満であることも，そのことを裏付けている。また， 静止画像の分析において, 全ての可視茶園は茶樹形状が識別でき る近景として区別された。これは, 全ての可視茶園が路線より $45 \mathrm{~m}$ 以内の比較的近い距離にあるといら結果と符合寸る。さらに, 高低差も $10 \mathrm{~m}$ 未満で緩斜地に立地している。つまり, 全ての可 視茶園は茶樹形状や管理状態が視認されやすい状況にあると言え る。一方，可視茶園の属性の内訳については，本来の仕立て形状 は 6 割, 収穫の機械化による畧仕立てが 3 割, 管理放棄され荒廃 したものが 1 割を占める。したがって，このような茶樹形状の違 いや管理状態の違いが沿道から識別されることとなる。沿道から の茶園景観を意識した整備では, 特に荒廃した 1 割の可視茶園の 再生や，本来の形状を保つ 6 割の茶園の維持に対する注力が必要 と考えられる。

\section{（2）茶園景観の特街}

図 - 3 は各路線において茶園が見え隠れする様子を現している。 その間隔は平均すると $117 \mathrm{~m}$ であり, $30 \mathrm{~km} / \mathrm{h}$ での移動を想定す ると見え隠れのリズムは 14 秒に 1 回となる。ただし, 分布の集 中寸る場所を通過する際には，次々と茶園が現れてくる様子を示 している。逆に，路線によっては茶園のほとんど現れない部分も ある。路線や通過場所によってリズムの違いはあるものの，短い 距離の中で，茶園が見え隠れするというシークエンスは，大井川 


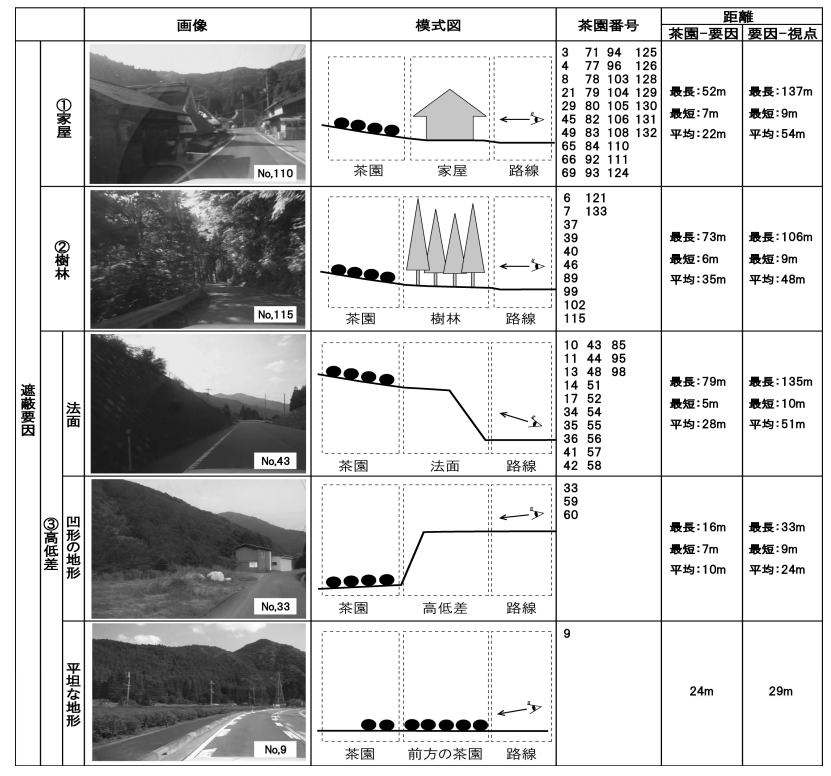

図 - 10 茶園の不可視要因

流域の茶園が比較的大規模に広がり，連続して視認されるシーク エンスや, 最長 $36 \mathrm{~km}$ に渡り茶園が確認される路線 6 ) と比較する と，本地域の景観の特徵の 1 つと言える。このような景観を来訪 者が容易に体験できるようにするためには，可視茶園の分布や沿 道からの可視性の情報を提供することが考えられる。ただし，茶 園の集中する場所は生活圈内に相当し得ることを一方で留意す心゙ きである。

また, 茶園別の静止画像の構成を分析した結果, 茶園と樹林・ 家屋の組み合わせが最多であった。これは茶園が基本的に集落内 の家屋に近接あるいは林縁に分布していることと一致する。視線 がさらに遠くへおよぶ場所では山稜が画面に加わり, 近景, 中景, 遠景のセットとなる。組み合わせとして次に多いのは，これに家 屋が含まれない場合である。つまり，近景の茶園，中景の樹林や 家屋，そして遠景の山稜へと続く景観が特徴と言える。このよう な景観を基調として, 図- 9 の 7 つのパターンに構成が変化する ことも本地域の沿道におけるシークエンス景観の特徵である。沿 道では建築物や看板の設置も考えられるが，特に遠景まで見通せ る視点場の保全には注力する必要がある。

\section{（3）茶園の可視性や景観の特徵の要因}

調查の結果, 茶園の可視性を低下させる遮蔽要素は, 家屋, 樹 林，高低差であることがわかった。それは，茶園が集落の中や林 縁に分布し家屋や樹林に近接していることに起因する。また，斜 面地に宅地や道路を造成したために生じた高低差もその一因を成 す。ただし, 家屋, 樹林, 高低差による遮蔽は, 図- 3 で示され る茶園の見え隠れといら特徴を生み出寸要因にもなっている。さ らに, 静止画像の構成において, 家屋と樹林は近景の茶園と遠景 の山稯の中間に位置している。家屋は茶園を営む人々の暮らしを 示寸存在である。また，樹林は山稜の一部である。つまり，茶園 の営農を想起させる家屋や山稜へと続く樹林が，近景と遠景の間 に位置することで，中山間部で茶園を営む農村景観のセットを作 り出寸要素となっている。茶園だけでなく, 家屋や樹林といった 諸要素との関係も, 景観計画の際に考慮すべきことを示している。

\section{5. 結論}

本地域において車両移動を想定した場合の沿道の茶園景観につ いて以下のことが明らかとなった。

a)沿道からの茶園の可視性は高くない。全体の過半数が視認でき ず，全貌を視衿できる茶園は1割にも満たない。 b)全ての可視茶園は茶樹形状や管理状態が視認されやすい距離に ある。しかし本来の仕立て形状は可視茶園の 6 割しかない一方, 管理放棄され荒廃したものが 1 割を占める。

c)移動とともに茶園の見え隠れが繰り返される。可視区間と不可 視区間が交互に現れる間隔は全路線平均で $117 \mathrm{~m}$ である。

d)近景の茶園, 中景の樹林や家屋, そして遠景の山稜へと続く景 観が特徴である。ただし，視点によっては家屋や山棱が含まれな い場合もある。

e)茶園は集落の中や林縁に分布し家屋, 樹林, 微地形による遮蔽 を受けるため, 可視性が低下寸る一方，見え隠れというシークエ ンス景観となる。また，家屋や樹林は近景の茶園と遠景の山稜を 結ぶ要素となっている。

f) 茶園の可視不可視や茶樹形状の視認のされやすさは, 景観要素 として茶園を位置つけ保全継承の方法を策定する際，対象の選定 の目安や根拠の 1 つとなり得る。また, 茶園の見え隠れという特 徵, そして, 近景から遠景までのセットといら特徵は, 増田ら

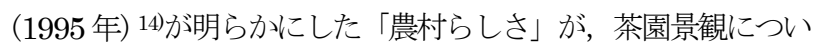
ても言えると考えられ, 今後の整備目標や整備内容の検討の一助 となり得る。

\section{6. 今後の課題}

本研究では車両移動を想定したが, 移動経路が各集落の主要動 線上に限られ，茶園の可視性が高くない状況下で可能性や課題を 検討した。集落と密接な位置関係にある茶園の分布状況を鑑みる に，歩行者による細街路の移動を想定した景観の把握も必要と考 えられる。

\section{補注及び引用文献}

1）農山漁村文化協会 (2008) : 茶大百科 I 歷史・文化品質・機能性I 品種製茶, $270 \mathrm{pp}$

2）谷口熊之助（1936）：ヤマチヤ調查報告: 茶業組合中央会議所

3）鳥屋尾忠之, 武田善行, 松下繁, 家弓実行, 近藤貞昭 (1996) : チヤ

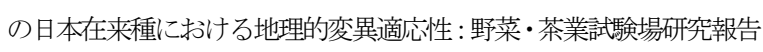
B(茶業) $9,1-29$

4）例えば，滋賀県近江八幡市は，2005 年に市内水鄉地域を景観計画地 域に指定し，琵琶湖の内湖周辺を景観農業振興地域として指定してい る。

5）荒井歩・植田寛（2010）：近代以前に形成された茶産地の景観構造： 東京農業大学集報 54(4), 307-314

6）鈴木利和・奥敬一 (2009) : 大井川中流域に㧍ける茶園景観の特徴と 評価構造 : ランドスケープ研究 72(5), 489-492

7）奥敬一・深町加津枝・三好岩生・堀内美緒（2009）: 大井川中流域の 茶園卓越景観における日中の来訪者による景観認識比較:ランドスケ 一プ研究 72(5), 657-660

8) 観光庁 (2011) : 観光白書, 9-10

9）雨宮護・横掁真・渡辺貴史 (2001)：沿道土地利用の違いからみた街 路樹の修景効果の解明 : ランドスケープ研究 64(5), 787-792

10）加藤㤑介・吉田博宣 (2004) : 史跡岡城跡におけるシークエンス景観 の分析 : ランドスケーブ研究 67(5), 637-642

11）柳田健太・小野良平・伊藤弓 ける車空からの景観の特性に関する研究: ランドスケープ研究 67 (5), 643-646

12）国土地理調查研究会編（1992）: 土地・水情報の基䃈と応用: 古今書 院, 192pp

13）樋口忠彦（1975）：景観の構造：技報堂出版，20-22

14）増田昇・安部大就・下村泰彦・山本聡・杉山富美（1995）: 堺市の南 部丘陵をケーススタディとする小流域を単位とした農村景観の評価 に関する研究: ランドスケープ研究 58(5), 169-172 